\title{
Efficacy and Safety of CGRP Monoclonal Antibodies for the Prevention of Migraine Compared with Placebo: A Systematic Review and Meta-Analysis
}

\author{
Xiaojing Yi \\ Hunan Normal University \\ Yun Chen \\ Hunan Normal University \\ Kun Chen \\ Hunan Normal University \\ Mo Liu \\ Hunan Normal University \\ Jiale Yi \\ Hunan Normal University \\ Xiongwei Hu \\ Hunan Normal University \\ Guibin Wang ( $\square$ 714010298@qq.com )
}

Research article

Keywords: Migraine, Calcitonin gene-related peptide, Monoclonal antibodies, Preventive treatment, Meta-analysis

Posted Date: July 14th, 2020

DOI: https://doi.org/10.21203/rs.3.rs-39329/v1

License: (c) (i) This work is licensed under a Creative Commons Attribution 4.0 International License. Read Full License 


\section{Abstract}

Background: Calcitonin gene-related peptide monoclonal antibodies (CGRP mAbs) are a novel class of drugs for migraine that includes erenumab, fremanezumab, galcanezumab and eptinezumab. In clinical trials, CGRP mAbs have been reported to show good efficacy in the prevention of episodic migraines or chronic migraines. Our aim was to evaluate the efficacy and safety of CGRP monoclonal antibodies in this study.

Methods: We systematically searched for randomized controlled trials in the PubMed, Embase, ClinicalTrials.gov, and Cochrane Library databases. The primary outcome was overall mean change from baseline to end of treatment in the number of monthly migraine headache days (MMHDs). The secondary outcomes included 50\% response rate, in the number of monthly headache days (MHDs), in the number of monthly headache hours (MHHs), and in the number of monthly acute migraine-specific medication days (MSMDs). The safety outcomes were evaluated in terms of reported adverse events.

Results: Eighteen studies including 11,099 patients were included in the meta-analysis. The meta-analysis showed that CGRP mAbs exhibited a significant benefit in reducing the number of MMHDs compared to placebo (Episodic migraine: Std. MD $-0.42,95 \% \mathrm{Cl}-0.47$ to -0.36 ; Chronic migraine: Std. MD $-0.28,95 \% \mathrm{Cl}-0.35$ to -0.21 ). Similarly, CGRP mAbs were superior to placebo in the secondary outcomes of $50 \%$ response rate, MHDs, MHHs, and MSMDs. With respect to safety, serious adverse events and withdrawal due to adverse events were not significantly associated with CGRP mAbs. Fremanezumab was associated with a significantly higher incidence of any adverse event compared with placebo (RR 1.10, 95\% $\mathrm{Cl} 1.03$ to 1.17). Galcanezumab was associated with significantly higher treatment-emergent adverse events compared with placebo (RR $1.11,95 \% \mathrm{Cl} 1.04$ to 1.17). Constipation and injection site pain were significantly higher with erenumab than placebo. Injection site erythema and injection site induration were significantly higher with fremanezumab than placebo. Upper respiratory tract infection, injection site erythema, injection site pruritus and injection site reaction were significantly higher with galcanezumab than placebo.

Conclusions: This study confirms that CGRP mAbs are effective as preventive treatments for episodic migraines and chronic migraines. Adverse reactions at the injection site were associated with erenumab, fremanezumab and galcanezumab therapy. Constipation was more common with erenumab. The risk of upper respiratory tract infection was higher with galcanezumab.

Systematic review registration: Our PROSPERO protocol registration number: CRD42019125928. Registered 26 November 2019.

\section{Introduction}

Migraines are a common primary neurological disease that can cause severe pain and disability; migraines are typically characterized by recurrent attacks of moderate to severe unilateral pulsating headache that are often accompanied by nausea, vomiting, dizziness, fatigue, photophobia, and phonophobia [1]. Migraines can be roughly divided into episodic migraines and chronic migraines depending upon the frequency of the attacks. Episodic migraines are defined as fewer than 15 days of migraines per month [1, 2]. Chronic migraines are defined as headaches that occur on 15 or more days per month for more than 3 months with at least 8 migraine days per month with symptoms that are consistent with the features of migraine headaches [1]. Episodic migraines can transform into chronic migraines [3]. The $2016 \mathrm{Global}$ Burden of Disease study estimated that 1.04 billion people worldwide had migraines, indicating an overall prevalence of $14.4 \%$ [4]. Migraines lead to heavy disease burdens for patients, family, and society. Migraines are the leading cause of neurological dysfunction worldwide and the second most disabling condition worldwide $[5,6]$.

Currently, the pharmacological management of migraines includes the treatment of acute attacks and prophylactic treatment. Acute treatment focuses on stopping migraines quickly, while preventive treatment aims to reduce the frequency and severity of migraines $[2,7]$. For migraine sufferers, preventive treatment is key. The current medications that are commonly used to prevent migraines include $\beta$ blockers, antidepressants, antiepileptics, and botulinum toxin [8]. Unfortunately, these migraine-preventing drugs usually have problematic or intolerable side effects, lack of efficacy and complex methods of administration, so patients have low compliance, and the drugs are often restricted in clinical application [9].

Calcitonin gene-related peptide (CGRP) is an important neuropeptide in the pathophysiology of migraines, and antagonizing CGRP or its receptor offers a new option for migraine management [10]. CGRP monoclonal antibodies (mAbs) are mainly used for the prevention of migraines. Four CGRP mAbs have been developed: three against CGRP itself, including fremanezumab (TEV-48215), galcanezumab (LY2951742), and eptinezumab (ALD403), and only one against the CGRP receptor, erenumab (AMG-334) [11]. In recent years, phase II and III randomized clinical trials have been completed that assessed the efficacy and safety of CGRP mAbs for chronic or episodic migraines, and full reports have been published one after another. Previous meta-analyses and systematic reviews analyzed only a small number of studies on episodic migraines [12-14], analyzed studies of a single CGRP monoclonal antibody [15], or only evaluated efficacy [16]. Additionally,

Page $2 / 20$ 
several new studies were not included in the published meta-analyses and systematic reviews. Therefore, the purpose of our systematic review and meta-analysis was to provide a comprehensive synthesis of current studies to update the efficacy and safety of CGRP mAbs in migraine prevention.

\section{Methods}

\section{Search Strategy and Selection Criteria}

We searched all references in the PubMed, Embase, ClinicalTrials.gov, and Cochrane Library databases from the date of their inception to July 2019, and then, an updated search was performed in January 2019. The search used the following terms: "headache", "migraine", "erenumab", "amg 334", "fremanezumab", "tev-48125", "galcanezumab", "ly 2951742", "eptinezumab", "placebo", "ald 403", "randomized controlled trial" and "human". Two reviewers (XJY and YC) independently reviewed the titles and abstracts from the search results to exclude duplicate studies, irrelevant studies, and studies that did not meet the eligibility criteria. When these reviewers disagreed, a third author (GBW) resolved the issue. The full texts of the potentially relevant studies were carefully reviewed, and the studies were included if: (1) the patients were adults, (2) the patients were diagnosed with migraines according to the International Classification of Headache Disorders, and (3) one or more primary or secondary outcomes were reported. A study was excluded if: (1) it did not report the outcomes of interest clearly, (2) it did not provide sufficient information to extract or calculate the data, (3) it included migraines secondary to other diseases, or (4) it was not a randomized placebo-controlled trial. This review has been accepted by PROSPERO (CRD42019125928).

\section{Primary and secondary outcomes}

The primary outcome was overall mean change from baseline to end of treatment in the number of monthly migraine headache days (MMHDs). The secondary outcomes included overall mean percentage of participants with reduction $\geq 50 \%$ in monthly migraine headache days ( $50 \%$ response rate), overall mean change in the number of monthly headache-days (MHDs), overall mean change in the number of monthly headache-hours (MHHs), and overall mean change in the number of monthly acute migraine-specific medication days (MSMDs). The safety outcomes were evaluated in terms of reported adverse events, including serious adverse events (SAEs), any adverse event, withdrawal due to adverse events, and treatment-emergent adverse events (TEAEs).

\section{Data extraction and risk of bias assessment}

Two reviewers (XJY and YC) independently extracted the relevant information from the eligible studies using specially designed extraction tables. When these reviewers disagreed, the issues were resolved through discussion or consultation with a third author (KC). The extracted information included the name of the first author, publication year, sources of the studies, study design, diagnostic criteria for migraines, types of migraines, number of patients on each arm, age, gender, interventions, outcomes, and adverse events. Moreover, two reviewers independently assessed the risk of bias of the eligible studies, including the selection bias (random sequence generation and allocation concealment), performance bias (blinding of participants and personnel), detection bias (blinding of outcome assessment), attrition bias (incomplete outcome data), reporting bias (selective outcome reporting), and other sources of bias, by using the Cochrane risk of bias tool for randomized trials.

\section{Data analysis}

The Review Manager software program, version 5.3, was used to conduct the statistical analyses. For continuous variables, standard mean difference (Std. MD) was selected for the analysis using the inverse variance (IV) method. For dichotomous variables, risk ratios (RRs) were selected for the analysis using the Mantel-Haenszel test. The precision of effect sizes was estimated using $95 \%$ confidence intervals (Cls). The degree of heterogeneity was evaluated using Cochrane's $Q$ test and the $l^{2}$ statistic. Substantial heterogeneity was indicated by the $p$ value of Cochran $Q$ lower than 0.10 or I-square higher than $50 \%$. The random-effects model was used when the data were significantly heterogeneous, and the fixed-effect model was used when the data were homogeneous. To reduced heterogeneity, quantitative synthesis analysis was conducted by using the subset design. The subset was stratified according to different types of drugs or types of migraines. Whenever significant heterogeneity was still present, we searched for potential sources of heterogeneity by omitting one study at a time from the meta-analysis. Funnel plots were used to determine publication bias regarding the end points.

\section{Results}

The initial search strategy yielded a total of 1361 references from the online databases, and 500 references were excluded because of duplication. Additionally, 838 references were excluded after screening the titles and abstracts, and 5 references were excluded after the full text was screened. Finally, eighteen studies were enrolled in the meta-analysis. A detailed flowchart of the study selection is shown in Fig. 1. In the pooled analysis, we did not summarize the low-dose groups of phase 2 clinical trials, including erenumab $7 \mathrm{mg} / 21 \mathrm{mg} / 28 \mathrm{mg}$,

Page $3 / 20$ 
galcanezumab $5 \mathrm{mg} / 50 \mathrm{mg}$, and eptinezumab $10 \mathrm{mg} / 30 \mathrm{mg}$; as these low-dose groups had only had only partial efficacy and did not enter phase 3 clinical trials.

\section{Study characteristics and study quality}

The eighteen included studies recruited 11,099 patients with migraines. Table 1 presents the characteristics of the included studies. Most of the patients were females ( $n=9405 ; 84.74 \%)$, and there were only 1694 males (15.33\%). Eighteen studies focused on four CGRP mAbs: erenumab (6), fremanezumab (5), galcanezumab (5), and eptinezumab (2). Twelve trials focused on episodic migraines, and five trials investigated chronic migraines. The other study recruited populations of both episodic migraine and chronic migraine patients. Moreover, two trials focused on patients who had documented failure to two to four classes of migraine preventive medications. The risk of bias in the studies is shown in Fig. 2. The risk of bias was low in almost all the studies. 
Table 1

Characteristics of included studies.

\begin{tabular}{|c|c|c|c|c|c|c|c|}
\hline Studies & $\begin{array}{l}\text { Trial } \\
\text { Registration }\end{array}$ & $\begin{array}{l}\text { Study } \\
\text { Design }\end{array}$ & $\begin{array}{l}\text { Migraine } \\
\text { Type* }\end{array}$ & Interventions & $\begin{array}{l}\text { Sex } \\
\text { (male/female) }\end{array}$ & $\begin{array}{l}\text { Age } \\
\text { (mean } \\
\pm \text { SD) }\end{array}$ & $\begin{array}{l}\text { Course of } \\
\text { Treatment }\end{array}$ \\
\hline $\begin{array}{l}\text { Bigal } \\
2015 a[17]\end{array}$ & NCT02021773 & $\begin{array}{l}\text { RCT } \\
\text { Phase } \\
2 b\end{array}$ & $\mathrm{C}$ & $\begin{array}{l}\text { Fremanezumab } 900 \text { mg/675-225- } \\
225 \text { mg/placebo }\end{array}$ & $37 / 227$ & $\begin{array}{l}40.7 \pm \\
12.0\end{array}$ & 3 months \\
\hline $\begin{array}{l}\text { Bigal } \\
2015 b[18]\end{array}$ & NCT02025556 & $\begin{array}{l}\text { RCT } \\
\text { phase } \\
2 b\end{array}$ & $\mathrm{E}$ & $\begin{array}{l}\text { Fremanezumab } \\
675 \mathrm{mg} / 225 \mathrm{mg} / \text { placebo }\end{array}$ & $36 / 261$ & $\begin{array}{l}41.2 \pm \\
12.2\end{array}$ & 3 months \\
\hline $\begin{array}{l}\text { Detke } \\
2018[19]\end{array}$ & NCT02614261 & $\begin{array}{l}\text { RCT } \\
\text { phase } \\
3\end{array}$ & $\mathrm{C}$ & $\begin{array}{l}\text { Galcanezumab } \\
240 \mathrm{mg} / 120 \mathrm{mg} / \text { placebo }\end{array}$ & $167 / 946$ & $\begin{array}{l}41.0 \pm \\
12.1\end{array}$ & 3 months \\
\hline $\begin{array}{l}\text { Dodick } \\
\text { 2014a [20] }\end{array}$ & NCT01625988 & $\begin{array}{l}\text { RCT } \\
\text { phase } \\
2\end{array}$ & $\mathrm{E}$ & Galcanezumab 150 mg/placebo & $33 / 184$ & $\begin{array}{l}41.4 \pm \\
11.5\end{array}$ & 3 months \\
\hline $\begin{array}{l}\text { Dodick } \\
\text { 2014b [21] }\end{array}$ & NCT01772524 & $\begin{array}{l}\text { RCT } \\
\text { phase } \\
2\end{array}$ & $\mathrm{E}$ & Eptinezumab 1000 mg/placebo & $30 / 133$ & $\begin{array}{l}38.8 \pm \\
10.2\end{array}$ & 2 months \\
\hline $\begin{array}{l}\text { Dodick } \\
\text { 2018a [22] }\end{array}$ & NCT02483585 & $\begin{array}{l}\text { RCT } \\
\text { phase } \\
3\end{array}$ & $\mathrm{E}$ & Erenumab 70 mg/placebo & $85 / 492$ & $\begin{array}{l}42.0 \pm \\
11.5\end{array}$ & 3 months \\
\hline $\begin{array}{l}\text { Dodick } \\
2018 b[23]\end{array}$ & NCT02629861 & $\begin{array}{l}\text { RCT } \\
\text { phase } \\
3\end{array}$ & $\mathrm{E}$ & $\begin{array}{l}\text { Fremanezumab } 675 \mathrm{mg} \text { single higher } \\
\text { dose/225 mg monthly/placebo }\end{array}$ & $133 / 742$ & $\begin{array}{l}41.8 \pm \\
12.1\end{array}$ & 3 months \\
\hline $\begin{array}{l}\text { Dodick } \\
2019[24]\end{array}$ & NCT02275117 & $\begin{array}{l}\text { RCT } \\
\text { phase } \\
2\end{array}$ & $\mathrm{C}$ & $\begin{array}{l}\text { Eptinezumab } \\
300 \mathrm{mg} / 100 \mathrm{mg} / 30 \text { mg/10 mg/placebo }\end{array}$ & $81 / 535$ & $\begin{array}{l}36.6 \pm \\
9.7\end{array}$ & 3 months \\
\hline $\begin{array}{l}\text { Ferrari } \\
2019[25]\end{array}$ & NCT03308968 & $\begin{array}{l}\text { RCT } \\
\text { phase } \\
3 \mathrm{~b}\end{array}$ & $\mathrm{E} / \mathrm{C}$ & $\begin{array}{l}\text { Fremanezumab } 675 \mathrm{mg} \\
\text { quarterly/225 mg monthly/placebo }\end{array}$ & $138 / 700$ & $\begin{array}{l}46.2 \pm \\
11.1\end{array}$ & 3 months \\
\hline $\begin{array}{l}\text { Goadsby } \\
2017[26]\end{array}$ & NCT02456740 & $\begin{array}{l}\text { RCT } \\
\text { phase } \\
3\end{array}$ & $\mathrm{E}$ & Erenumab $140 \mathrm{mg} / 70 \mathrm{mg} / \mathrm{placebo}$ & $141 / 814$ & $\begin{array}{l}40.9 \pm \\
11.2\end{array}$ & 6 months \\
\hline $\begin{array}{l}\text { Reuter } \\
2018[27]\end{array}$ & NCT03096834 & $\begin{array}{l}\text { RCT } \\
\text { phase } \\
3 \mathrm{~b}\end{array}$ & $\mathrm{E}$ & Erenumab 140 mg/placebo & $46 / 200$ & $\begin{array}{l}44.4 \pm \\
10.5\end{array}$ & 3 months \\
\hline $\begin{array}{l}\text { Sakai } \\
2019[28]\end{array}$ & NCT02630459 & $\begin{array}{l}\text { RCT } \\
\text { phase } \\
2\end{array}$ & $\mathrm{E}$ & $\begin{array}{l}\text { Erenumab } \\
140 \mathrm{mg} / 70 \mathrm{mg} / 28 \mathrm{mg} / \mathrm{placebo}\end{array}$ & $75 / 400$ & $\begin{array}{l}44.0 \pm \\
8.6\end{array}$ & 6 months \\
\hline $\begin{array}{l}\text { Silberstein } \\
2017[29]\end{array}$ & NCT02621931 & $\begin{array}{l}\text { RCT } \\
\text { phase } \\
3\end{array}$ & $\mathrm{C}$ & $\begin{array}{l}\text { Fremanezumab } 675 \text { mg quatrerly/675- } \\
225-225 \mathrm{mg} / \text { placebo }\end{array}$ & $139 / 991$ & $\begin{array}{l}41.3 \pm \\
12.1\end{array}$ & 3 months \\
\hline $\begin{array}{l}\text { Skljarevski } \\
2018 a[30]\end{array}$ & NCT02163993 & $\begin{array}{l}\text { RCT } \\
\text { phase } \\
2 b\end{array}$ & $\mathrm{E}$ & $\begin{array}{l}\text { Galcanezumab } 300 \mathrm{mg} \\
120 \mathrm{mg} / 50 \mathrm{mg} / 5 \mathrm{mg} / \text { placebo }\end{array}$ & $70 / 340$ & $\begin{array}{l}40.2 \pm \\
12.0\end{array}$ & 3 months \\
\hline $\begin{array}{l}\text { Skljarevski } \\
2018 b[31]\end{array}$ & NCT02614196 & $\begin{array}{l}\text { RCT } \\
\text { phase } \\
3\end{array}$ & $\mathrm{E}$ & $\begin{array}{l}\text { Galcanezumab } \\
240 \mathrm{mg} / 120 \mathrm{mg} / \text { placebo }\end{array}$ & $134 / 781$ & $\begin{array}{l}41.8 \pm \\
11.2\end{array}$ & 6 months \\
\hline $\begin{array}{l}\text { Stauffer } \\
2018[32]\end{array}$ & NCT02614183 & $\begin{array}{l}\text { RCT } \\
\text { phase } \\
3\end{array}$ & $\mathrm{E}$ & $\begin{array}{l}\text { Galcanezumab } \\
240 \mathrm{mg} / 120 \mathrm{mg} / \text { placebo }\end{array}$ & $140 / 718$ & $\begin{array}{l}40.7 \pm \\
11.6\end{array}$ & 6 months \\
\hline $\begin{array}{l}\text { Sun } 2016 \\
\text { [33] }\end{array}$ & NCT01952574 & $\begin{array}{l}\text { RCT } \\
\text { phase } \\
2\end{array}$ & $\mathrm{E}$ & Erenumab 70 mg/21 mg/7 mg/placebo & $94 / 389$ & $\begin{array}{l}41.3 \pm \\
10.7\end{array}$ & 3 months \\
\hline
\end{tabular}

* C: chronic migraine, E: episodic migraine. 


\begin{tabular}{|llllllll|}
\hline Studies & $\begin{array}{l}\text { Trial } \\
\text { Registration }\end{array}$ & $\begin{array}{l}\text { Study } \\
\text { Design }\end{array}$ & $\begin{array}{l}\text { Migraine } \\
\text { Type* }\end{array}$ & Interventions & $\begin{array}{l}\text { Sex } \\
\text { (male/female) }\end{array}$ & $\begin{array}{l}\text { Age } \\
\text { (mean } \\
\pm \text { SD) }\end{array}$ & $\begin{array}{l}\text { Course of } \\
\text { Treatment }\end{array}$ \\
\hline $\begin{array}{l}\text { Tepper } \\
2017 \text { [34] }\end{array}$ & NCT02066415 & $\begin{array}{l}\text { RCT } \\
\text { phase } \\
2\end{array}$ & C & Erenumab $140 \mathrm{mg} / 70 \mathrm{mg} /$ placebo & $115 / 552$ & $42.1 \pm$ & 3 months \\
\hline
\end{tabular}

\section{Publication bias}

The probability of publication bias was estimated only by the visual inspection of a funnel plot, since the Review Manager software program, version 5.3, was used. We presented only a funnel plot of the primary outcome, and there was no obvious asymmetry in the funnel plot (Fig. 3) by visual analysis.

\section{MMHDs}

The meta-analysis of MMHDs included seventeen trials with a total of 10,007 patients. Obviously, CGRP mAbs were superior in reducing MMHDs compared with placebo for the prevention of migraine (Episodic migraine subgroup, Std. MD $-0.42,95 \% \mathrm{Cl}-0.47$ to $-0.36, \mathrm{I}^{2}=7 \%$; Chronic migraine subgroup, Std. MD $-0.28,95 \% \mathrm{Cl}-0.35$ to $-0.21, \mathrm{I}^{2}=13 \%$; Fig. 4). The test for subgroup differences reflected a high heterogeneity among the three subsets $($-square $=91.1 \%)$.

\section{$50 \%$ response rate}

Of the 18 studies, seventeen trials with a total of 9061 patients reported data abouts the $50 \%$ response rate. CGRP mAbs led to a significantly higher $50 \%$ response rate compared with placebo for the prevention of migraines (Episodic migraine subgroup, $\mathrm{RR} 1.61,95 \% \mathrm{Cl}$ 1.51 to $1.72, I^{2}=47 \%$; Chronic migraine subgroup, RR $1.61,95 \% \mathrm{Cl} 1.41$ to $1.83, \mathrm{I}^{2}=13 \%$; Fig. 5). The subgroup differences were mainly due to the episodic and migraine subsets, which included only Ferrari 2019. In the sensitivity analysis, after the exclusion of Sakai 2019, the RR of the $50 \%$ response rate was $1.58\left(95 \% \mathrm{Cl}: 1.48\right.$ to $1.69, \mathrm{I}^{2}=18 \%$ ) in the episodic migraines prevented by CGRP mAbs compared with the episodic migraines prevented by placebo.

\section{MHDs and MHHs}

Regarding the MHDs, seven trials with a total of 3480 patients reported this outcome. There was a significant difference between CGRP mAbs and placebo in the decrease in MHDs (Episodic migraine: Std. MD $-0.31,95 \% \mathrm{Cl}-0.44$ to $-0.18, \mathrm{I}^{2}=26 \%$; Chronic migraine: Std. MD $-0.28,95 \% \mathrm{Cl}-0.36$ to $-0.20, \mathrm{I}^{2}=17 \%$; Fig. $6 \mathrm{a}$ ). Regarding the MHHs, seven trials with a total of 4346 patients reported this outcome. Similarly, there was a significant difference between CGRP mAbs and placebo in the decrease in MHHs (Episodic migraine: Std. MD $-0.34,95 \% \mathrm{Cl}-0.42$ to $-0.25, I^{2}=0 \%$; Chronic migraine: Std. MD $-0.23,95 \% \mathrm{Cl}-0.31$ to $-0.15, \mathrm{l}^{2}=0 \%$; Fig. $6 \mathrm{~b}$ ).

MSMDs

Seven trials with a total of 3911 patients reported the MSMDs. Using a random -effect model, CGRP mAbs were associated with significantly reduced MSMDs (Std. MD $-0.56,95 \% \mathrm{Cl}-0.67$ to $-0.45, \mathrm{I}^{2}=60 \%$; Fig. 7) compared with placebo. In the sensitivity analysis, after the exclusion of Dodick 2018a, the same significant result was observed (Std. MD $-0.60,95 \% \mathrm{Cl}-0.70$ to $-0.51, \mathrm{I}^{2}=33 \%$ ). Due to the insufficient number of studies, we did not conduct subgroup analysis by type of migraine.

\section{Adverse events}

The adverse events were used to evaluate the safety of the drugs. Currently, the CGRP mAbs used to prevent migraine include erenumab, fremanezumab, galcanezumab, and epitinezumab. Therefore, subgroup analysis was used to assess the safety of each CGRP mAb. Fremanezumab was associated with significantly higher incidence of any adverse event when compared with placebo (RR $1.10,95 \% \mathrm{Cl} 1.03$ to $1.17, \mathrm{I}^{2}=0 \%$; Additional file1: S1), and no differences were observed between erenumab and placebo (RR $0.97,95 \% \mathrm{Cl} 0.91$ to $1.04, \mathrm{I}^{2}=$ 39\%; Additional file1: S1). Regarding TEAEs, no significant differences were observed between fremanezumab and placebo (RR $1.06,95 \% \mathrm{Cl}$ 0.89 to $1.27, I^{2}=57 \%$; Additional file1: S2), while the incidence of TEAEs after treatment with galcanezumab was significantly higher compared with treatment with placebo (RR $1.11,95 \% \mathrm{Cl} 1.04$ to $1.17, \mathrm{I}^{2}=0 \%$; Additional file1: S2). Unfortunately, the subgroup of fremanezumab included two studies with a high heterogeneity. All the included studies reported withdrawal due to adverse events and SAEs. 
No significant differences were observed in the withdrawal due to adverse events and SAEs between the four CGRP mAbs and placebo (Additional file1: S3 and S4).

\section{Common adverse events reported in included studies}

We analyzed the common adverse events of each CGRP mAb with fixed-effect model. For erenumab, the results showed that the rates of constipation and injection site pain were significantly higher compared to placebo (RR $2.01,95 \% \mathrm{Cl} 1.06$ to $3.82, \mathrm{I}^{2}=31 \%$; $\mathrm{RR} 1.80,95 \% \mathrm{Cl}$ 1.10 to $2.94, I^{2}=4 \%$; Table 2 ). For galcanezumab, the meta-analysis showed that the rates of upper respiratory tract infection (RR $1.45,95 \%$ Cl 1.03 to $2.05, \mathrm{I}^{2}=0 \%$ ), injection site pain (RR $1.31,95 \% \mathrm{Cl} 1.07$ to $1.60, \mathrm{I}^{2}=67 \%$ ), injection site erythema (RR $2.69,95 \% \mathrm{Cl} 1.63$ to $4.45, \mathrm{I}^{2}=$ $0 \%$ ), injection site pruritus ( $\mathrm{RR} 15.99,95 \% \mathrm{Cl} 4.47$ to $57.24, \mathrm{I}^{2}=0 \%$ ), and injection site reaction ( $\mathrm{RR} 4.70,95 \% \mathrm{Cl} 2.68$ to $\left.8.25, \mathrm{I}^{2}=69 \%\right)$ were significantly higher compared with placebo (details are shown in Table 3 ). There was high heterogeneity in injection site pain and injection site reaction. In the sensitivity analysis, after the exclusion of Skljarevski 2018a, no differences were noted between galcanezumab and placebo in terms of injection site pain (RR $1.22,95 \% \mathrm{Cl} 0.99$ to $1.50, \mathrm{I}^{2}=46 \%$ ). For injection site reaction, this outcome was still significant after the exclusion of Skljarevski $2018 \mathrm{~b}$ (RR 3.03, 95\% Cl 1.66 to $5.50, \mathrm{I}^{2}=20 \%$ ). For fremanezumab, the incidence of injection site erythema and injection site induration were significantly higher compared with placebo (RR $1.29,95 \% \mathrm{Cl} 1.06$ to $1.57, \mathrm{I}^{2}=0 \%$; $\mathrm{RR} 1.27,95 \% \mathrm{Cl} 1.05$ to $1.53, I^{2}=0 \%$; Table 4). There were only two studies on epitinezumab in the included studies, and we analyzed the adverse events reported jointly by these two studies. The results showed that epitinezumab led to rates of dizziness, nausea, migraine, and upper respiratory tract infection that were similar to those caused by placebo (Table 5).

Table 2

Common adverse events of erenumab and placebo.

\begin{tabular}{|lllllll|}
\hline Common adverse events & Number of studies & Erenumab & Placebo & RR & P & $\mathbf{A}^{\mathbf{2}}$ \\
\hline Nausea & 4 & $33 / 1400$ & $28 / 1043$ & $0.91[0.55,1.52]$ & 0.73 & $0 \%$ \\
\hline Fatigue & 4 & $30 / 1141$ & $19 / 885$ & $1.27[0.73,2.22]$ & 0.41 & $0 \%$ \\
\hline Constipation & 4 & $41 / 1566$ & $13 / 1026$ & $2.01[1.06,3.82]$ & 0.03 & $31 \%$ \\
\hline Back pain & 4 & $26 / 1130$ & $15 / 732$ & $1.14[0.60,2.18]$ & 0.69 & $0 \%$ \\
\hline Arthralgia & 2 & $15 / 739$ & $11 / 472$ & $0.88[0.38,2.02]$ & 0.75 & $29 \%$ \\
\hline Migraine & 4 & $24 / 1400$ & $23 / 1043$ & $0.80[0.46,1.39]$ & 0.44 & $49 \%$ \\
\hline Nasopharyngitis & 6 & $185 / 1791$ & $129 / 1303$ & $0.89[0.72,1.10]$ & 0.27 & $30 \%$ \\
\hline Sinusitis & 2 & $24 / 916$ & $13 / 608$ & $1.19[0.60,2.35]$ & 0.62 & $0 \%$ \\
\hline Upper respiratory tract infection & 5 & $71 / 1519$ & $39 / 1167$ & $1.30[0.89,1.90]$ & 0.18 & $0 \%$ \\
\hline Influenza & 3 & $24 / 1022$ & $21 / 761$ & $0.93[0.51,1.68]$ & 0.8 & $0 \%$ \\
\hline Injection site pain & 5 & $51 / 1751$ & $24 / 1150$ & $1.80[1.10,2.94]$ & 0.02 & $4 \%$ \\
\hline
\end{tabular}


Table 3

Common adverse events of galcanezumab and placebo.

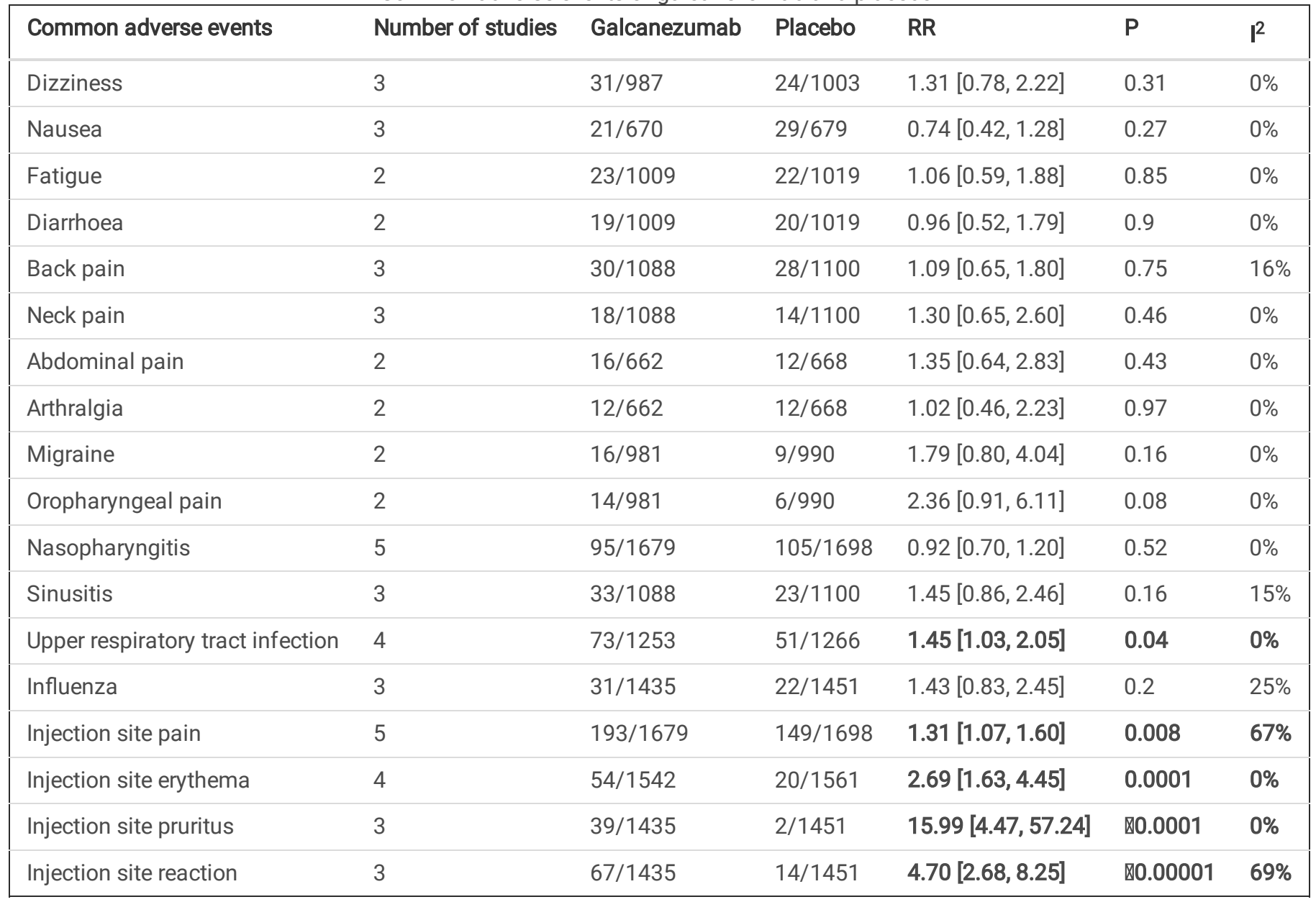


Table 4

Common adverse events of fremanezumab and placebo.

\begin{tabular}{|c|c|c|c|c|c|c|}
\hline Common adverse events & Number of studies & Fremanezumab & Placebo & RR & P & $P^{2}$ \\
\hline Dizziness & 3 & $35 / 1508$ & $8 / 756$ & $2.10[1.00,4.40]$ & 0.05 & $0 \%$ \\
\hline Nausea & 4 & $28 / 2089$ & $26 / 1049$ & $0.54[0.32,0.92]$ & 0.02 & $16 \%$ \\
\hline Fatigue & 3 & $31 / 1334$ & $8 / 674$ & $1.95[0.90,4.23]$ & 0.09 & $0 \%$ \\
\hline Constipation & 2 & $11 / 735$ & $2 / 366$ & $2.30[0.59,8.96]$ & 0.23 & $0 \%$ \\
\hline Insomnia & 2 & $16 / 735$ & $2 / 366$ & $3.29[0.87,12.35]$ & 0.08 & $0 \%$ \\
\hline Paraesthesia & 2 & $5 / 366$ & $3 / 193$ & $0.83[0.22,3.17]$ & 0.78 & $68 \%$ \\
\hline Back pain & 3 & $15 / 927$ & $8 / 470$ & $0.96[0.41,2.24]$ & 0.92 & $0 \%$ \\
\hline Neck pain & 2 & $7 / 735$ & $0 / 366$ & $4.02[0.50,32.06]$ & 0.19 & $0 \%$ \\
\hline Arthralgia & 2 & $7 / 753$ & $3 / 381$ & $1.10[0.31,3.84]$ & 0.89 & $12 \%$ \\
\hline Migraine & 2 & $4 / 366$ & $2 / 193$ & $0.95[0.20,4.46]$ & 0.95 & $0 \%$ \\
\hline Headache & 2 & $7 / 366$ & $2 / 193$ & $1.58[0.38,6.61]$ & 0.53 & $48 \%$ \\
\hline Nasopharyngitis & 5 & $82 / 2263$ & $46 / 1138$ & $0.89[0.63,1.27]$ & 0.53 & $0 \%$ \\
\hline Sinusitis & 4 & $29 / 1702$ & $22 / 861$ & $0.67[0.39,1.16]$ & 0.15 & $0 \%$ \\
\hline Upper respiratory tract infection & 4 & $80 / 2089$ & $37 / 1049$ & $1.09[0.74,1.59]$ & 0.67 & $0 \%$ \\
\hline Depression & 2 & $2 / 366$ & $3 / 193$ & $0.39[0.09,1.78]$ & 0.23 & $62 \%$ \\
\hline Influenza & 2 & $11 / 753$ & $3 / 381$ & $1.86[0.52,6.64]$ & 0.34 & $0 \%$ \\
\hline Bronchitis & 2 & $15 / 773$ & $3 / 397$ & $2.28[0.72,7.21]$ & 0.16 & $0 \%$ \\
\hline Injection site pain & 5 & $433 / 2263$ & 197/1138 & $1.10[0.95,1.27]$ & 0.19 & $0 \%$ \\
\hline Injection site erythema & 5 & $308 / 2263$ & $119 / 1138$ & $1.29[1.06,1.57]$ & 0.01 & $0 \%$ \\
\hline Injection site pruritus & 3 & $16 / 927$ & $3 / 470$ & $2.15[0.73,6.35]$ & 0.16 & $0 \%$ \\
\hline Injection site bruising & 3 & $15 / 927$ & $5 / 470$ & $1.54[0.56,4.20]$ & 0.4 & $0 \%$ \\
\hline Injection site induration & 3 & $317 / 1897$ & $125 / 945$ & $1.27[1.05,1.53]$ & 0.01 & $0 \%$ \\
\hline Injection site hemorrhage & 2 & $27 / 1336$ & $16 / 668$ & $0.84[0.46,1.55]$ & 0.59 & $0 \%$ \\
\hline
\end{tabular}

Table 5

Common adverse events of eptinezumab and placebo.

\begin{tabular}{|lllllll|}
\hline Common adverse events & Number of studies & Eptinezumab & Placebo & RR & P & $\mathbf{l}^{2}$ \\
\hline Dizziness & 2 & $17 / 324$ & $10 / 203$ & $0.95[0.45,1.99]$ & 0.89 & $22 \%$ \\
\hline Nausea & 2 & $20 / 324$ & $11 / 203$ & $1.02[0.50,2.08]$ & 0.95 & $0 \%$ \\
Migraine & 2 & $9 / 324$ & $4 / 203$ & $1.36[0.40,4.66]$ & 0.63 & $0 \%$ \\
\hline Upper respiratory tract infection & 2 & $28 / 324$ & $12 / 203$ & $1.50[0.77,2.94]$ & 0.23 & $0 \%$ \\
\hline
\end{tabular}

\section{Discussion}

This study compared the efficacy and safety of four different CGRP mAbs compared to those of placebo for migraine prevention. The present meta-analysis included 18 studies including a total of 11,099 migraine patients. The analysis showed that patients with migraines who received CGRP mAbs experienced significantly reduced MMHDs, MHDs, MHHs, and MSMDs and increased $50 \%$ response rate compared with patients who received placebo. In addition to MSMDs, we performed a subgroup analysis of the above outcomes, which showed that CGRP mAbs showed significant efficacy in both episode migraines and chronic migraines, and the results were reliable and stable. The results were similar to those of previous meta-analyses, which included only episodic migraines or chronic migraines[14, 35-37]. 
In terms of safety, there were no significant differences between CGRP mAbs and placebo in terms of SAEs and withdrawal due to adverse events. However, the incidence of any adverse event was significantly higher after treatment with fremanezumab, and TEAEs were significantly higher after treatment with galcanezumab, compared to treatment with placebo.

Regarding the common adverse events, nasopharyngitis, upper respiratory tract infection and adverse reactions at the injection site were the most frequently reported adverse events. By summarizing the analysis, we observed a noteworthy finding. Constipation and injection site pain were significantly higher after treatment with erenumab than after treatment with placebo. Injection site erythema and injection site induration were significantly higher after treatment with fremanezumab than after treatment with placebo. Upper respiratory tract infection, injection site erythema, injection site pruritus and injection site reaction were significantly higher after treatment with galcanezumab than after treatment with placebo. Adverse reactions at the injection site seem to be common among CGRP mAbs (except for eptinezumab); however, according to the literature, most of these adverse reactions were mild to moderate and rarely led to discontinuation[38]. In most previous studies and reviews, there was no significant difference in the incidence of noninjection site adverse events between the CGRP mAbs group and the placebo group. In our analysis, we found that constipation was associated with the use of erenumab, and the use of fremanezumab increased the risk of upper respiratory tract infection. Constipation has been reported to be the most significant adverse effect of erenumab in clinical practice, but this was not observed in clinical trials, which may be related to study duration[39]. Upper respiratory tract infection is a common adverse event of CGRP mAbs, but previous clinical studies have not shown that fremanezumab use increases the risk of upper respiratory tract infection. Does fremanezumab affect immune function? This question deserves our attention and should be scrutinized in clinical application.

Regarding eptinezumab, it is currently the only CGRP mAb administered intravenously. In our meta-analysis, only two articles reported the results of clinical studies of eptinezumab, and these articles included a total of 779 participants, which was lower than the numbers of participants included in the other trials. Therefore, the safety and efficacy of eptinezumab should be carefully considered. Since eptinezumab is administered via intravenous injection, unlike other CGRP mAbs administered by percutaneous injection, there are few adverse reactions at the injection site. Although the two key clinical trials of eptinezumab, Promise- 1 and Promise-2, have been completed, the complete data are not available at the time of writing, and we look forward to further updates to confirm the safety and efficacy of eptinezumab.

CGRP is a neuropeptide that is widely found in the peripheral and central nervous system. CGRP regulates pain perception and maintains neurogenic inflammation, which further leads to peripheral and central pain sensitization, which may play a role in the pathogenesis of migraines[40]. Therefore, CGRP has become a new target for the treatment of migraines. To date, two drugs have been developed to target CGRP, including small molecule CGRP receptor antagonists and CGRP mAbs. A small molecule CGRP receptor antagonist, known as gepants, was designed for the treatment of acute migraines, but previous studies have been limited by potential hepatotoxicity or other causes[41]. While mAbs are mainly used to prevent migraine, their intended goal was to achieve high targeting specificity and minimal systemic adverse reactions. The role of mAbs in migraine prevention has not been fully elucidated. The ability of these monoclonal antibodies to cross the blood-brain barrier is very limited, suggesting that their role may lie primarily outside the blood-brain barrier[42]. Since CGRP is an effective vasodilator that may play a protective role in the cardiovascular system, a future issue to be addressed is the safety of mAbs in patients with long-term or increased cardiovascular risk. Moreover, it is also important to identify the appropriate patient population. The Ferrari 2019 and Reuter 2018 studies included in this meta-analysis show rapid effectiveness and good tolerance in the prevention of migraine attacks in difficult-to-treat migraine patients who previously did not respond to up to four classes of migraine preventive drugs[25, 27]. Compared with those of placebo, the treatment benefits were higher than previous studies using other migraine preventive medications.

Our study has several advantages compared with previous meta-analyses. First, we systematically and comprehensively searched the literature. All the included randomized controlled trials were rigorously evaluated, and a total of 18 studies with low risks of bias were included. Second, we evaluated several related results. Third, we used appropriate subgroup analysis. Our analysis also has some limitations. First, due to limited data, we only focused on short-term, double-blinded controlled studies that lasted no more than half a year, and long-term efficacy and safety were unclear. Second, there are differences in the included studies, such as the severity of the migraines and the course and dosage of the medications, which may lead to significant heterogeneity. Third, we did not pay attention to the differences in treatment time and dose of the different types of CGRP mAbs.

\section{Conclusions}

This study confirms that CGRP mAbs are effective as preventive treatments for episodic migraines and chronic migraines. Adverse reactions at the injection site were associated with erenumab, fremanezumab and galcanezumab. Constipation was more commonly associated with erenumab. The risk of upper respiratory tract infection was higher with galcanezumab. In general, CGRP mAbs are effective in preventing

Page $10 / 20$ 
migraine, and have certain reference and guiding value for clinicians and migraine patients. However, further clinical trials and clinical applications are still needed to verify its safety.

\section{Abbreviations}

CGRP mAbs: Calcitonin gene-related peptide monoclonal antibodies; MMHDs:monthly migraine headache days; MHDs:monthly headache days; MHHs:monthly headache hours; MSMDs:monthly acute migraine-specific medication days; SAEs:serious adverse events;

TEAEs:treatment-emergent adverse events.

\section{Declarations}

\section{Ethics approval and consent to participate}

The manuscript is not a clinical trial and does not contain individual patient data, and therefore does not require ethics committee approval or patient consent.

\section{Consent for publication}

Not applicable.

\section{Availability of data and materials}

All data generated or analysed during this study are included in this published article and its supplementary information files.

\section{Competing interests}

The authors declare no competing interests.

\section{Funding}

This research received no external funding.

\section{Author Contributions}

XJY, ML, XWH, and GBW contributed to the study conception and design. Systematic literature search, selected studies for inclusion and extracted data were performed by XJY and YC. Statistical analyses were by ML and KC. XJY and YC made the Fig.s. GBW and XWH were responsible for supervision and management. XJY and JLY wrote the first draft of the manuscript. All authors read and approved the final manuscript.

\section{Acknowledgements}

Not applicable.

\section{References}

1. Headache Classification Committee of the International Headache Society (IHS) The International Classification of Headache Disorders, 3rd edition. Cephalalgia: an international journal of headache. 2018;38(1):1-211

2. Goadsby PJ, Sprenger T (2010) Current practice and future directions in the prevention and acute management of migraine. Lancet Neurol 9(3):285-298

3. Su M, Yu S (2018) Chronic migraine: A process of dysmodulation and sensitization. Mol Pain 14:17448069187676971744806918767697

4. Disease GBD, Injury I, Prevalence C (2018) Global, regional, and national incidence, prevalence, and years lived with disability for 354 diseases and injuries for 195 countries and territories, 1990-2017: a systematic analysis for the Global Burden of Disease Study 2017. Lancet 392(10159):1789-1858

5. Buse DC, Scher Al, Dodick DW, Reed ML, Fanning KM, Manack Adams A, Lipton RB Impact of Migraine on the Family: Perspectives of People With Migraine and Their Spouse/Domestic Partner in the CaMEO Study. Mayo Clinic proceedings. 2016

6. Burch RC, Buse DC, Lipton RB, Migraine (2019) Epidemiology, Burden, and Comorbidity. Neurologic Clinics 37(4):631-649 
7. Silberstein SD (2017) Current management: migraine headache. CNS Spectr 22(S1):1-13

8. Loder E, Rizzoli PP (2018) Prevention of Migraine: A Narrative Review of the State of the Art in 2018. Headache 58(Suppl 3):218-229

9. Tessitore A, Russo A (2019) Is targeting CGRP the right pathway to prevent migraine? Lancet 394(10203):984-986

10. Tso AR, Goadsby PJ, Anti (2017) -CGRP Monoclonal Antibodies: the Next Era of Migraine Prevention? Curr Treat Options Neurol 19(8):27-27

11. Rujan R-M, Reynolds CA (2019) Calcitonin Gene-Related Peptide Antagonists and Therapeutic Antibodies. Handb Exp Pharmacol 255:169-192

12. Hong P, Wu X, Liu Y (2017) Calcitonin gene-related peptide monoclonal antibody for preventive treatment of episodic migraine: A meta analysis. Clinical neurology neurosurgery 154:74-78

13. Xu D, Chen D, Zhu LN, Tan G, Wang HJ, Zhang Y, Liu L (2019) Safety and tolerability of calcitonin-gene-related peptide binding monoclonal antibodies for the prevention of episodic migraine - a meta-analysis of randomized controlled trials. Cephalalgia: an international journal of headache 39(9):1164-1179

14. Zhu Y, Liu Y, Zhao J, Han Q, Liu L, Shen X (2018) The efficacy and safety of calcitonin gene-related peptide monoclonal antibody for episodic migraine: a meta-analysis. Neurological sciences: official journal of the Italian Neurological Society of the Italian Society of Clinical Neurophysiology 39(12):2097-2106

15. Ren Z, Zhang H, Wang R, Yuan Q, Pan L, Chen C (2019) The treatment efficacy of galcanezumab for migraine: A meta-analysis of randomized controlled trials. Clinical neurology neurosurgery 186:105428

16. Huang, IH;Wu, P-C, Lin E-Y, Chen C-Y, Kang Y-N (2019) Effects of Anti-Calcitonin Gene-Related Peptide for Migraines: A Systematic Review with Meta-Analysis of Randomized Clinical Trials. Int J Mol Sci 20(14):3527

17. Bigal ME, Edvinsson L, Rapoport AM, Lipton RB, Spierings EL, Diener HC, Burstein R, Loupe PS, Ma Y, Yang R et al (2015) Safety, tolerability, and efficacy of TEV-48125 for preventive treatment of chronic migraine: a multicentre, randomised, double-blind, placebocontrolled, phase 2b study. The Lancet Neurology 14(11):1091-1100

18. Bigal ME, Dodick DW, Rapoport AM, Silberstein SD, Ma Y, Yang R, Loupe PS, Burstein R, Newman LC, Lipton RB (2015) Safety, tolerability, and efficacy of TEV-48125 for preventive treatment of high-frequency episodic migraine: a multicentre, randomised, double-blind, placebo-controlled, phase 2b study. The Lancet Neurology 14(11):1081-1090

19. Detke HC, Goadsby PJ, Wang S, Friedman DI, Selzler KJ, Aurora SK (2018) Galcanezumab in chronic migraine: The randomized, doubleblind, placebo-controlled REGAIN study. Neurology 91(24):e2211-e2221

20. Dodick DW, Goadsby PJ, Spierings ELH, Scherer JC, Sweeney SP, Grayzel DS (2014) Safety and efficacy of LY2951742, a monoclonal antibody to calcitonin gene-related peptide, for the prevention of migraine: A phase 2, randomised, double-blind, placebo-controlled study. The Lancet Neurology 13(9):885-892

21. Dodick DW, Goadsby PJ, Silberstein SD, Lipton RB, Olesen J, Ashina M, Hirman J, Smith J, Wilks K, Kudrow D et al (2014) Safety and efficacy of ALD403, an antibody to calcitonin gene-related peptide, for the prevention of frequent episodic migraine: a randomised, double-blind, placebo-controlled, exploratory phase 2 trial. The lancet neurology 13(11):1100-1107

22. Dodick DW, Ashina M, Brandes JL, Kudrow D, Lanteri-Minet M, Osipova V, Palmer K, Picard H, Mikol DD, Lenz RA (2018) ARISE: A Phase 3 randomized trial of erenumab for episodic migraine. Cephalalgia: an international journal of headache 38(6):1026-1037

23. Dodick DW, Silberstein SD, Bigal ME, Yeung PP, Goadsby PJ, Blankenbiller T, Grozinski-Wolff M, Yang R, Ma Y, Aycardi E (2018) Effect of Fremanezumab Compared With Placebo for Prevention of Episodic Migraine: A Randomized Clinical Trial. Jama 319(19):1999-2008

24. Dodick DW, Lipton RB, Silberstein S, Goadsby PJ, Biondi D, Hirman J, Cady R, Smith J (2019) Eptinezumab for prevention of chronic migraine: A randomized phase 2b clinical trial. Cephalalgia: an international journal of headache 39(9):1075-1085

25. Ferrari MD, Diener HC, Ning X, Galic M, Cohen JM, Yang R, Mueller M, Ahn AH, Schwartz YC, Grozinski-Wolff M et al (2019) Fremanezumab versus placebo for migraine prevention in patients with documented failure to up to four migraine preventive medication classes (FOCUS): a randomised, double-blind, placebo-controlled, phase 3b trial. Lancet 394(10203):1030-1040

26. Goadsby PJ, Reuter U, Hallström Y, Broessner G, Bonner JH, Zhang F, Sapra S, Picard H, Mikol DD, Lenz RA (2017) A Controlled Trial of Erenumab for Episodic Migraine. New England journal of medicine 377(22):2123-2132

27. Reuter U, Goadsby PJ, Lanteri-Minet M, Wen S, Hours-Zesiger P, Ferrari MD, Klatt J (2018) Efficacy and tolerability of erenumab in patients with episodic migraine in whom two-to-four previous preventive treatments were unsuccessful: a randomised, double-blind, placebo-controlled, phase 3b study. Lancet 392(10161):2280-2287

28. Sakai F, Takeshima T, Tatsuoka Y, Hirata K, Lenz R, Wang Y, Cheng S, Hirama T, Mikol DD (2019) A Randomized Phase 2 Study of Erenumab for the Prevention of Episodic Migraine in Japanese Adults. Headache 59(10):1731-1742

Page $12 / 20$ 
29. Silberstein SD, Dodick DW, Bigal ME, Yeung PP, Goadsby PJ, Blankenbiller T, Grozinski-Wolff M, Yang R, Ma Y, Aycardi E (2017) Fremanezumab for the Preventive Treatment of Chronic Migraine. The New England journal of medicine 377(22):2113-2122

30. Skljarevski V, Oakes TM, Zhang Q, Ferguson MB, Martinez J, Camporeale A, Johnson KW, Shan Q, Carter J, Schacht A et al (2018) Effect of Different Doses of Galcanezumab vs Placebo for Episodic Migraine Prevention: a Randomized Clinical Trial. JAMA neurology 75(2):187-193

31. Skljarevski V, Matharu M, Millen BA, Ossipov MH, Kim BK, Yang JY (2018) Efficacy and safety of galcanezumab for the prevention of episodic migraine: Results of the EVOLVE-2 Phase 3 randomized controlled clinical trial. Cephalalgia: an international journal of headache 38(8):1442-1454

32. Stauffer VL, Dodick DW, Zhang Q, Carter JN, Ailani J, Conley RR (2018) Evaluation of Galcanezumab for the Prevention of Episodic Migraine: The EVOLVE-1 Randomized Clinical Trial. JAMA neurology 75(9):1080-1088

33. Sun H, Dodick DW, Silberstein S, Goadsby PJ, Reuter U, Ashina M, Saper J, Cady R, Chon Y, Dietrich J et al (2016) Safety and efficacy of AMG 334 for prevention of episodic migraine: a randomised, double-blind, placebo-controlled, phase 2 trial. The Lancet Neurology 15(4):382-390

34. Tepper S, Ashina M, Reuter U, Brandes, JL;Doležil, D, Silberstein S, Winner P, Leonardi D, Mikol D, Lenz R (2017) Safety and efficacy of erenumab for preventive treatment of chronic migraine: a randomised, double-blind, placebo-controlled phase 2 trial. The Lancet Neurology 16(6):425-434

35. Hou M, Xing H, Cai Y, Li B, Wang X, Li P, Hu X, Chen J (2017) The effect and safety of monoclonal antibodies to calcitonin gene-related peptide and its receptor on migraine: a systematic review and meta-analysis. The journal of headache pain 18(1):42

36. Deng H, Li GG, Nie H, Feng YY, Guo GY, Guo WL, Tang ZP (2020) Efficacy and safety of calcitonin-gene-related peptide binding monoclonal antibodies for the preventive treatment of episodic migraine - an updated systematic review and meta-analysis. BMC Neurol 20(1):57

37. Han L, Liu Y, Xiong H, Hong P (2019) CGRP monoclonal antibody for preventive treatment of chronic migraine: An update of metaanalysis. Brain behavior 9(2):e01215

38. Charles A, Pozo-Rosich P (2019) Targeting calcitonin gene-related peptide: a new era in migraine therapy. Lancet (London England) 394(10210):1765-1774

39. Arca K, Reynolds J, Sands KA, Shiue HJ Calcitonin Gene-Related Peptide Antagonists for the Prevention of Migraine: Highlights From Pivotal Studies and the Clinical Relevance of This New Drug Class. The Annals of pharmacotherapy. 2020:1060028020903417

40. Yuan H, Lauritsen CG, Kaiser EA, Silberstein SD (2017) CGRP Monoclonal Antibodies for Migraine: Rationale and Progress. BioDrugs: clinical immunotherapeutics biopharmaceuticals gene therapy 31(6):487-501

41. Negro A, Martelletti P (2019) Gepants for the treatment of migraine. Expert opinion on investigational drugs 28(6):555-567

42. Paemeleire, K;MaassenVanDenBrink, A (2018) Calcitonin-gene-related peptide pathway mAbs and migraine prevention. Current opinion in neurology 31(3):274-280

\section{Figures}


Records identified by searching $(n=1361)$

PubMed $(n=100)$

Cochrane Library $(n=567)$

Embase $(n=675)$

Clinicaltrials.gov $(n=19)$

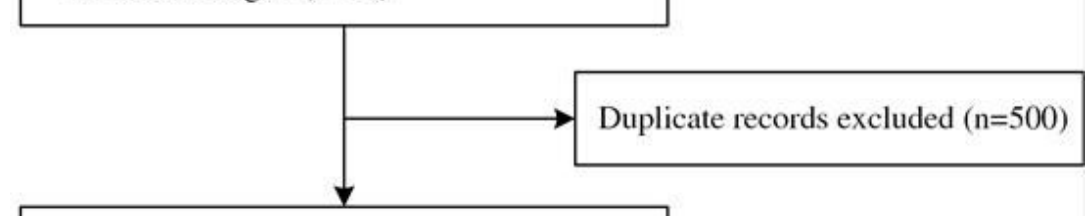

Screened by titles and abstracts $(n=861)$

Excluded $(\mathrm{n}=838)$

Conference abstracts $(n=606)$

Irrelevant records $(n=101)$

Study protocols $(\mathrm{n}=62)$

Review/meta articles $(n=43)$

Duplicate publications $(\mathrm{n}=26)$

Full-text articles assessed for eligibility $(n=23)$

Excluded $(\mathrm{n}=5)$

Overlapping study $(\mathrm{n}=5)$

Studies included in the meta-analysis $(\mathrm{n}=18)$

\section{Figure 1}

Flowchart of study selection 


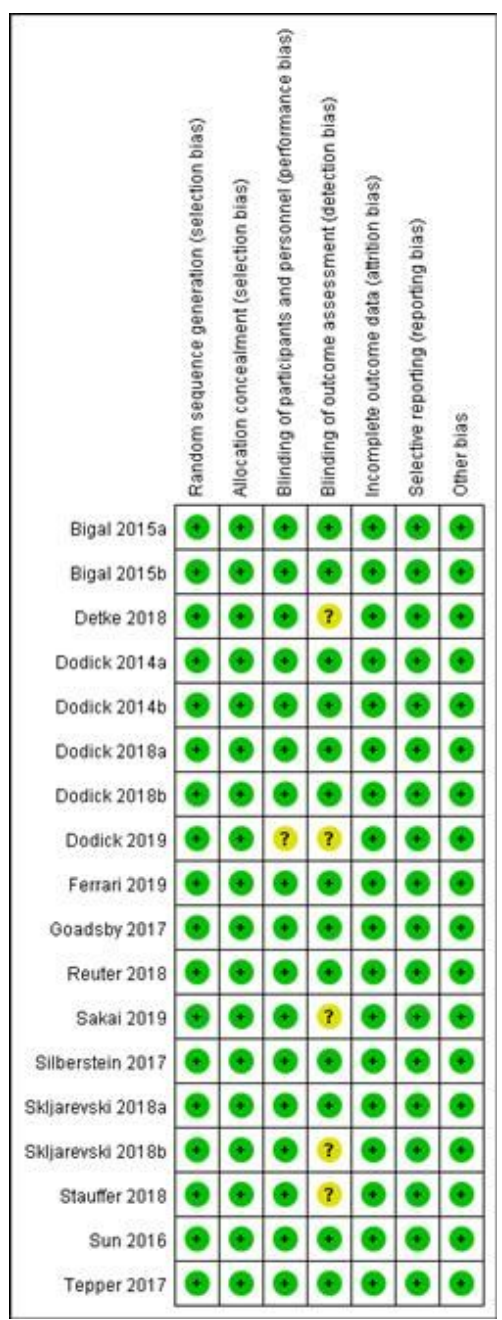

Figure 2

Risk of bias assessment summary of each study 


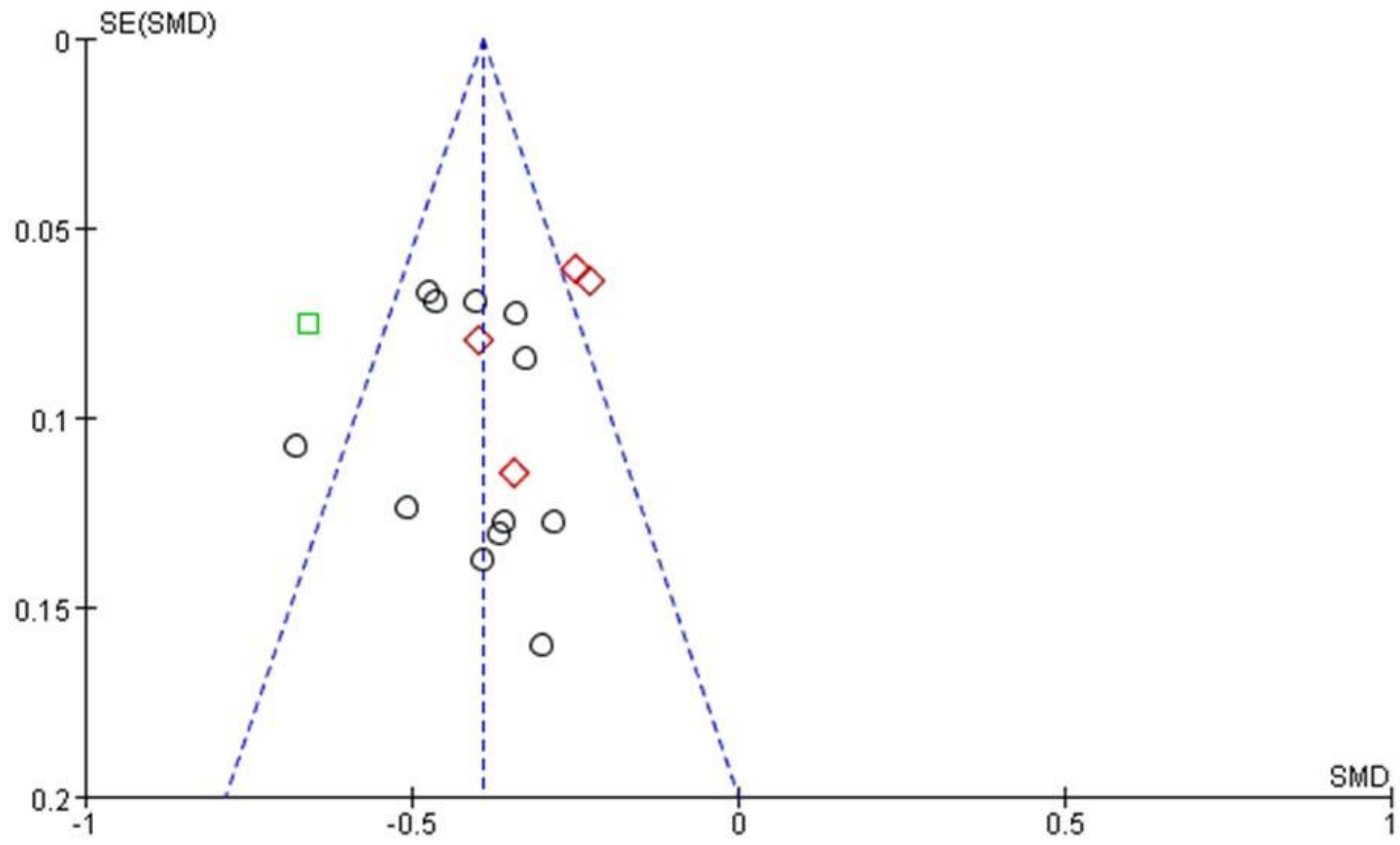

$\begin{array}{ll} & \text { Subgroups } \\ \text { Episodic migraine } & \square \text { Episodic and chronic migraine }\end{array}$

Figure 3

A funnel plot estimating of publication bias. 


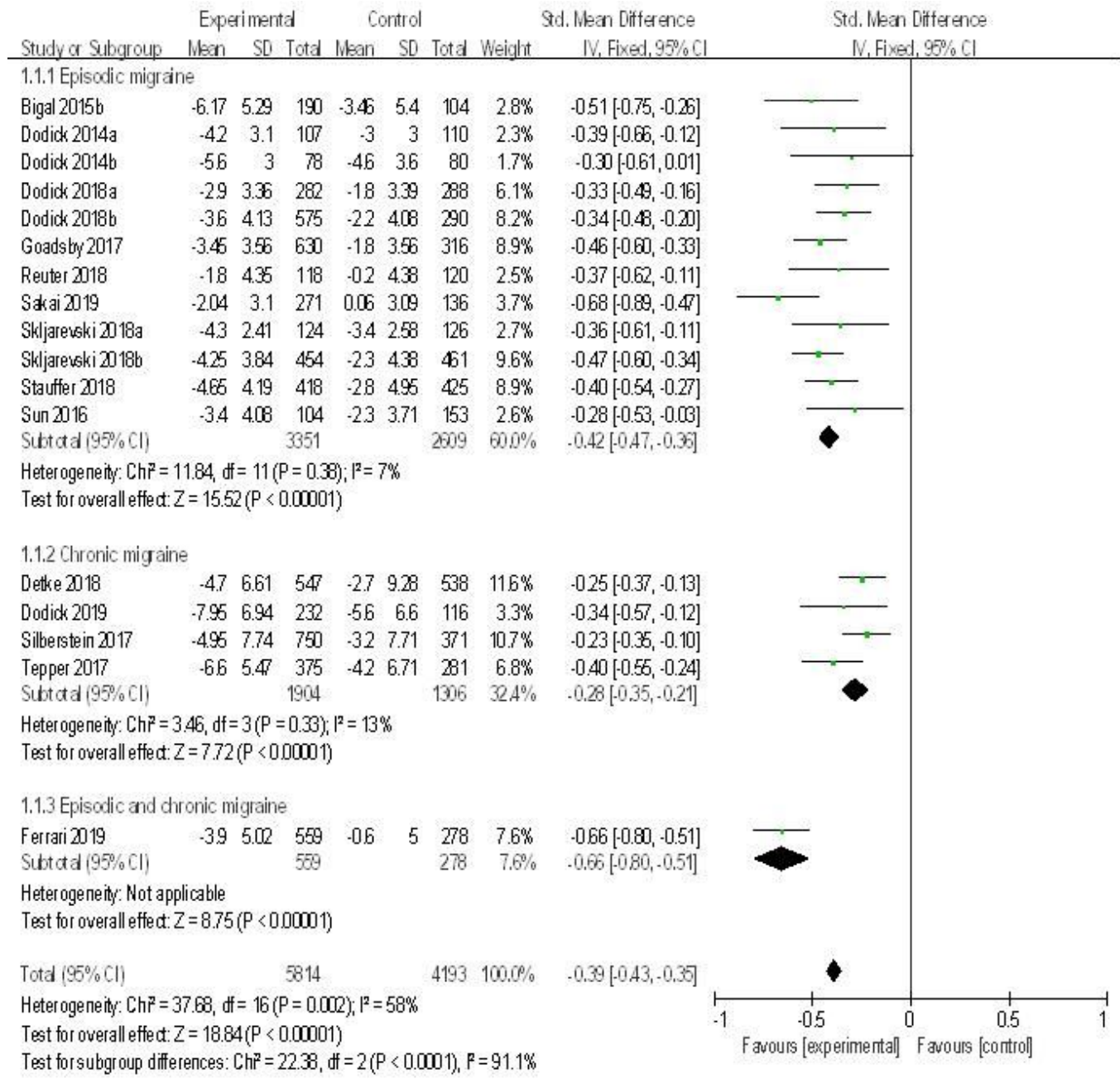

\section{Figure 4}

MMHDs of CGRP mAbs and placebo. 


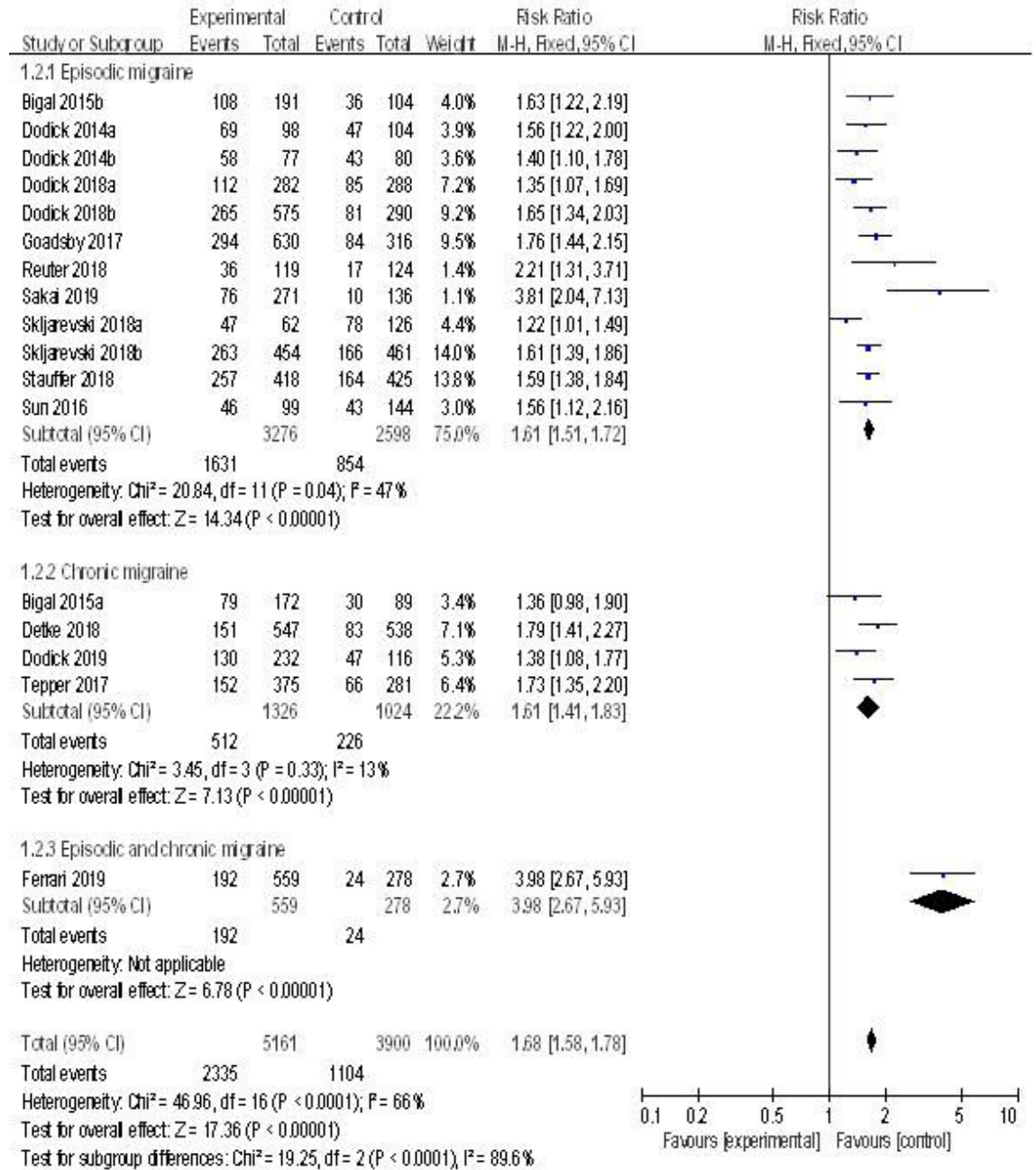

Figure 5

$50 \%$ response rate of CGRP mAbs and placebo. 


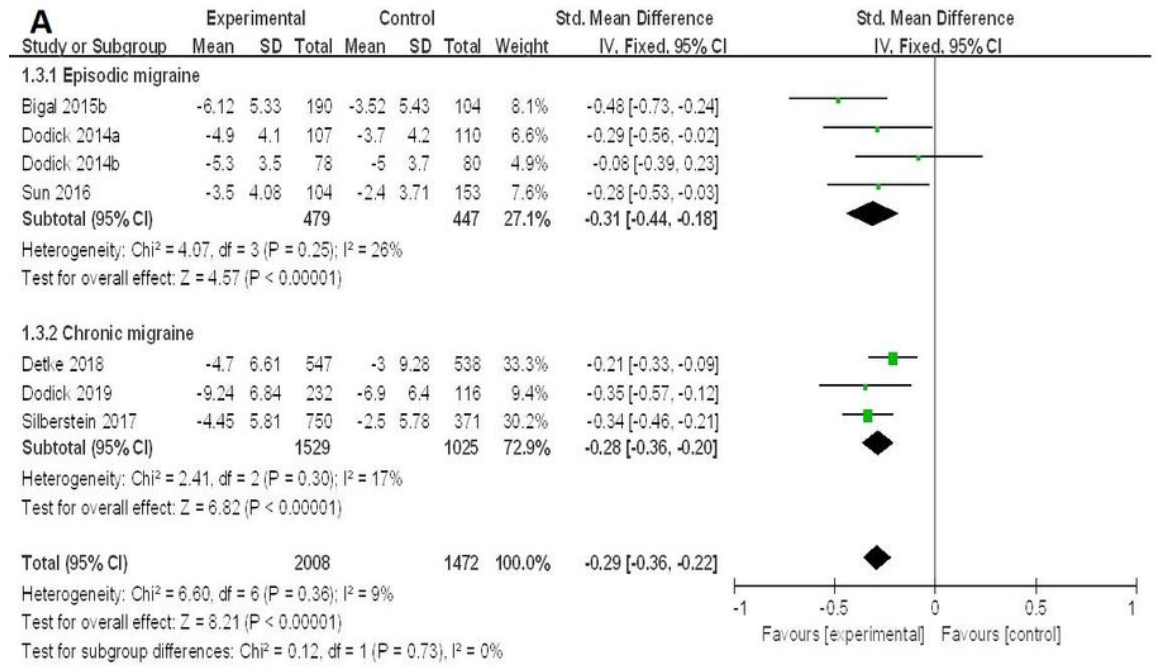

\section{B}

\begin{tabular}{|c|c|c|c|c|c|c|c|c|c|c|c|}
\hline \multirow[b]{2}{*}{ Study or Subgroup } & \multicolumn{3}{|c|}{ Experimental } & \multicolumn{3}{|c|}{ Control } & \multicolumn{2}{|c|}{ Std. Mean Difference } & \multirow{2}{*}{\multicolumn{3}{|c|}{$\begin{array}{c}\text { Std. Mean Difference } \\
\text { IV. Fixed, } 95 \% \mathrm{Cl}\end{array}$}} \\
\hline & Mean & SD & Total & Mean & SD & Total & Weight & IV. Fixed. $95 \% \mathrm{Cl}$ & & & \\
\hline \multicolumn{12}{|c|}{ 1.4.1 Episodic migraine } \\
\hline Skjarevshi 2018b & -25.27 & 36.18 & 446 & -10.89 & 40.73 & 450 & $20.9 \%$ & $-0.37[-0.50,-0.24]$ & & & \\
\hline Stauffer 2018 & -29.48 & 39.13 & 418 & -15.57 & 46.18 & 425 & $19.7 \%$ & $-0.32[-0.46,-0.19]$ & & & \\
\hline Sun 2016 & -33.4 & 52.01 & 104 & -20.4 & 53.19 & 153 & $5.8 \%$ & $-0.25[-0.50,0.00]$ & & & \\
\hline Subtotal $(95 \% \mathrm{Cl})$ & & & 968 & & & 1028 & $46.5 \%$ & $-0.34[-0.42,-0.25]$ & & & \\
\hline \multicolumn{12}{|c|}{ Heterogeneity: $\mathrm{Chi}^{2}=0.83, \mathrm{df}=2(\mathrm{P}=0.66) ; 1^{2}=0 \%$} \\
\hline \multicolumn{12}{|c|}{ Test for overall effect: $Z=7.44(P<0.00001)$} \\
\hline \multicolumn{12}{|c|}{ 1.4.2 Chronic migraine } \\
\hline Eigal 2015a & .63 .63 & 79.74 & 172 & -37.1 & 79.44 & 89 & $5.5 \%$ & $-0.33[-0.59,-0.07]$ & & & \\
\hline Dethe 2018 & -33.85 & 77.69 & 547 & -13.4 & 90.46 & 538 & $25.6 \%$ & $-0.24[-0.36,-0.12]$ & $\longrightarrow-$ & & \\
\hline Dodick 2019 & .67 .29 & 108.43 & 232 & -38.7 & 99.3 & 116 & $7.3 \%$ & $-0.27[-0.49,-0.05]$ & & & \\
\hline Tepper 2017 & -69.64 & 94.48 & 375 & -55.2 & 95,55 & 281 & $15.2 \%$ & $-0.15[-0.31,0.00]$ & & & \\
\hline Subtotal $(95 \% \mathrm{Cl})$ & & & 1326 & & & 1024 & $53.5 \%$ & $-0.23[-0.31,-0.15]$ & & & \\
\hline \multicolumn{12}{|c|}{ Heterogeneity: $\mathrm{Chi}^{2}=1.75, \mathrm{df}=3(\mathrm{P}=0.63) ; 1^{2}=0 \%$} \\
\hline \multicolumn{12}{|c|}{ Test for overall effect: $Z=5.46(P<0.00001)$} \\
\hline Total $(95 \% \mathrm{Cl})$ & & & 2294 & & & 2052 & $100.0 \%$ & $-0.28[-0.34,-0.22]$ & & & \\
\hline \multicolumn{9}{|c|}{ Heterogeneity: $\mathrm{Ch}^{2}=5.55, \mathrm{df}=6(\mathrm{P}=0.48) ; 1^{2}=0 \%$} & $-1 \quad-0.5$ & $0 \quad 0.5$ & 1 \\
\hline $\begin{array}{l}\text { Test for overall effect: } \\
\text { Test for subgroup diffe }\end{array}$ & 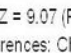 & $\begin{array}{l}P<0.000 \\
\text { hi }^{2}=2.98\end{array}$ & 1001) & & 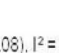 & $=66.4 \%$ & & & Favours [e perimental] & ] Favours [control] & \\
\hline
\end{tabular}

\section{Figure 6}

a MHDs of CGRP mAbs and placebo; $b$ MHHs of CGRP mAbs and placebo. 
Experimental Control Std. Mean Difference Std. Mean Difference

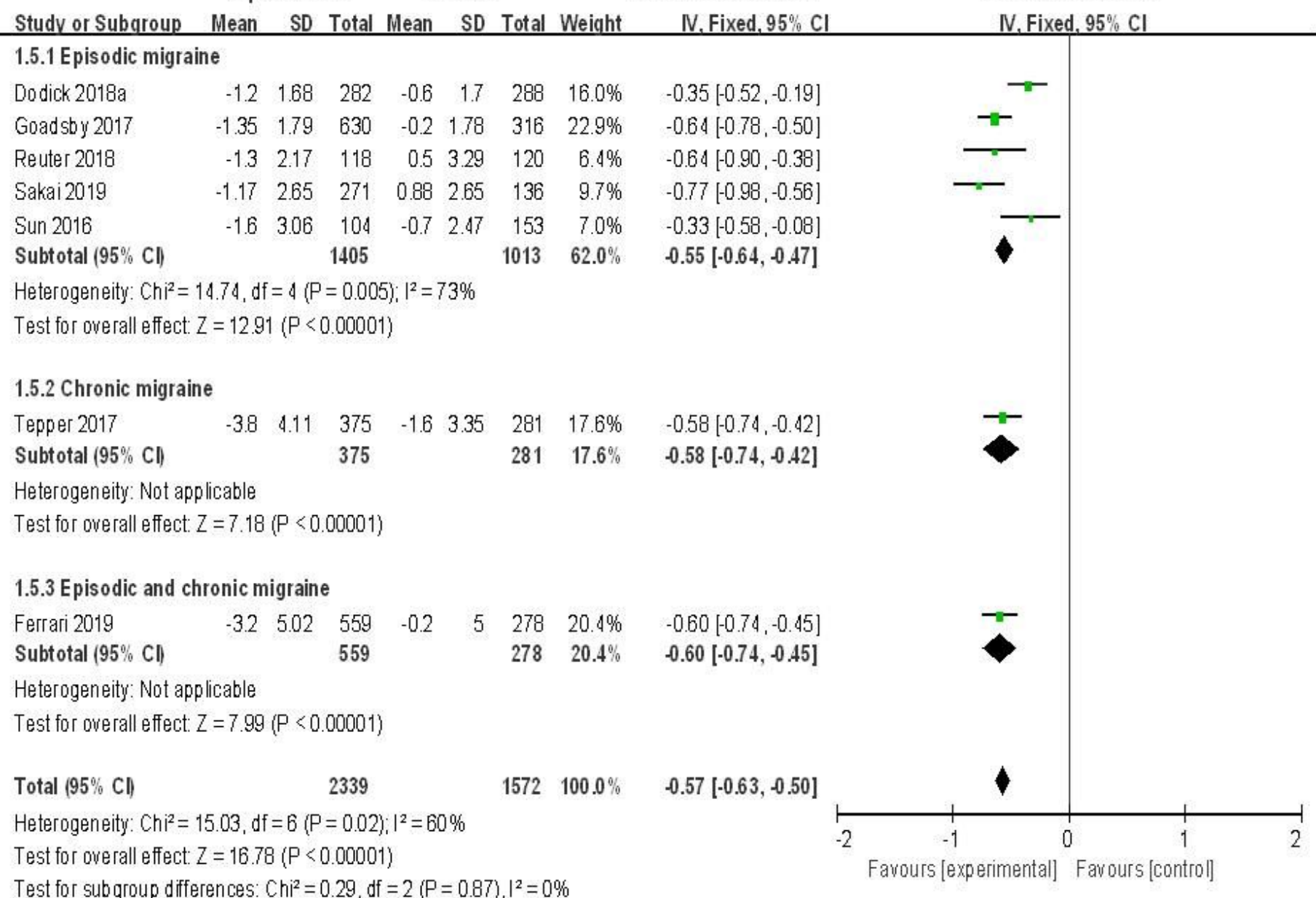

\section{Figure 7}

MSMDs of CGRP mAbs and placebo

\section{Supplementary Files}

This is a list of supplementary files associated with this preprint. Click to download.

- Additionalfile1.docx 